This article was downloaded by: [George Mason University], [Mr Paul Gorski]

On: 17 January 2012, At: 07:15

Publisher: Routledge

Informa Ltd Registered in England and Wales Registered Number: 1072954 Registered office: Mortimer House, 37-41 Mortimer Street, London W1T 3J H, UK

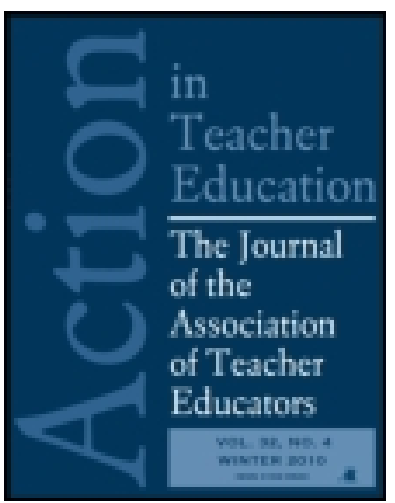

\title{
Action in Teacher Education
}

Publication details, including instructions for authors and subscription information:

http:// www.tandfonline.com/ loi/ uate20

\section{Is There a "Hierarchy of Oppression" in U.S. Multicultural Teacher Education Coursework?}

\author{
Paul C. Gorski ${ }^{a} \&$ Rachael D. Goodman ${ }^{a}$ \\ ${ }^{a}$ George Mason University \\ Available online: $11 \mathrm{~J}$ an 2012
}

To cite this article: Paul C. Gorski \& Rachael D. Goodman (2011): Is There a "Hierarchy of Oppression" in U.S. Multicultural Teacher Education Coursework?, Action in Teacher Education, 33:5-6, 455-475

To link to this article: http:// dx. doi.org/ 10.1080/01626620.2011.627305

\section{PLEASE SCROLL DOWN FOR ARTICLE}

Full terms and conditions of use: http://www.tandfonline.com/page/terms-and-conditions

This article may be used for research, teaching, and private study purposes. Any substantial or systematic reproduction, redistribution, reselling, loan, sub-licensing, systematic supply, or distribution in any form to anyone is expressly forbidden.

The publisher does not give any warranty express or implied or make any representation that the contents will be complete or accurate or up to date. The accuracy of any instructions, formulae, and drug doses should be independently verified with primary sources. The publisher shall not be liable for any loss, actions, claims, proceedings, demand, or costs or damages whatsoever or howsoever caused arising directly or indirectly in connection with or arising out of the use of this material. 


\title{
Is There a "Hierarchy of Oppression" in U.S. Multicultural Teacher Education Coursework?
}

\author{
Paul C. Gorski \\ Rachael D. Goodman \\ George Mason University
}

\begin{abstract}
Thirty years ago Audre Lorde famously argued that there is no, or ought not to be, a "hierarchy of oppression"; that the notion that one identity or oppression trumps another is, itself, oppression. Around the same time, many multicultural education theorists and practitioners, initially focused largely on race, began to incorporate other equity concerns. Despite today's widely, although not universally, shared notion that it is concerned with all forms of equity, research has shown that a hierarchy of oppression remains visible in multicultural education theory and practice. In this study the authors analyzed course schedules from a sample $(N=41)$ of multicultural teacher education (MTE) course syllabi and data from a survey $(N=122)$ of people who teach MTE courses to ascertain whether a systemic hierarchy of oppression exists in MTE coursework. The authors found that such a hierarchy does, indeed, exist. Implications are discussed from an intersectionality theory perspective.
\end{abstract}

In 1983, Audre Lorde wrote,

Within the lesbian community I am Black, and within the Black community I am a lesbian. Any attack against Black people is a lesbian and gay issue, because I and thousands of other Black women are part of the lesbian community. Any attack against lesbians and gays is a Black issue, because thousands of lesbians and gay men are Black. (p. 9)

Famously, Lorde concluded, "There is no hierarchy of oppression."

Gorski, the first author of this article, first read these words 16 years ago as a graduate education student enrolled in a multicultural education course. By that time those six words-there is no hierarchy of oppression - had come to constitute somewhat of a mantra in some multicultural education circles. The words, or the sentiments behind them, commonly are thrust forth with conviction during conference presentations and workshops. They appear in articles (see, e.g., McDonald \& Coleman, 1999). There is no hierarchy of oppression: this has become, in our experience, part of the ethos, perhaps even part of the "common sense" (Kumashiro, 2008), of multicultural education, at least theoretically.

Of course, it was not always this way, not even theoretically. Multicultural education, having grown out of the U.S. Civil Rights movement of the 1950s and 1960s, initially focused largely, if not exclusively, on racial equity concerns (Banks, 2010; Davidman \& Davidman,

Correspondence should be addressed to Paul C. Gorski, George Mason University, Integrative Studies, 4400 University Dr., MS 5D3, Fairfax, VA 22030-4444. E-mail: gorski@edchange.edu 
1997). Throughout the 1970s and 1980s it grew to encompass other identities and oppressions, including gender and sexism, sexual orientation and heterosexism, language and linguicism, class and economic injustice, and disability and ableism (Banks, 2010; Grant \& Sleeter, 2008). However, this expansion was not universal, neither in theory nor in practice. An array of evidence suggests that race continues to dominate discourses, scholarship, and practice related to multicultural and diversity education today and that other identities and oppressions garner considerably less attention in those discourses and contexts (Amosa \& Gorski, 2008; Clark, 2010), including multicultural teacher education (MTE) (Gorski, 2010).

As Marshall (2009) demonstrated, some people prominently placed in the multicultural education milieu have maintained that race, given its dominant role in the construction and stratification of U.S. society and schools, ought to remain the predominate concern in U.S. multicultural education theory and practice, even at the expense of attention to other identities and oppressions. Other individuals, including Lorde (1983), have argued that, though race is, indeed, a central concern in U.S. society generally and in multicultural discourses more specifically, it is not the central concern; after all, equity and social justice, two guiding principles of multicultural education (Gorski, 2006; Nieto \& Bode, 2011), require attention to all identities and oppressions. Still other individuals, drawing on intersectionality theory (Nakano Glenn, 1999; Risman, 2004; Shields, 2008), have argued that we limit our understandings whenever we attempt to look at any one of these identities or oppressions outside of the context of the other peoples' identities and oppressions (Rivière, 2005).

Given these theoretical and philosophical divergences, we wondered to what extent a "hierarchy of oppression" exists in a particular, and particularly unique, multicultural education context. The purpose of this study was to answer the question, Is there a "hierarchy of oppression" in MTE courses taught in the United States? To answer that question, we sought to identify whether certain identities and oppressions are privileged over others in MTE courses and, if so, to what extent they are privileged. We imagined privilege in this sense as having two dimensions: time and depth. We wondered whether comparably more attention was given to some identities and oppressions than other identities and oppressions in MTE courses and whether deeper or more critical attention was afforded some identities and oppressions than other identities and oppressions. We chose to focus specifically on MTE courses because, as Cochran-Smith (2003) and Scott and Ford (2011) explained, a single "multicultural" course represents the lone opportunity most teacher candidates or classroom teachers have to examine equity concerns during formal teacher preparation processes. With this limitation in mind, we conceptualized "multicultural teacher education courses" as courses focused centrally and explicitly on diversity, multiculturalism, social justice, and directly related topics that are offered in education programs at U.S. colleges and universities.

To uncover whether such privileging existed and, if it did, what the hierarchy looked like, we applied quantitative analysis techniques to two primary sources of data. The first source consisted of a sample of 41 detailed course schedules as codified on MTE course syllabi from colleges and universities around the United States. These data enabled us to calculate the percentage of class time devoted, on average, to various identities and oppressions in a sample of U.S.-based MTE courses.

However, syllabi and course schedules are inexact for a variety of reasons, so we felt that additional data were needed. We designed and disseminated a survey $(N=122)$ to people who recently have taught or are teaching MTE courses in the United States. The survey was designed to identify the identity- and oppression-related topics and theoretical frameworks multicultural 
teacher educators (people who teach MTE courses) were most likely to incorporate into their MTE courses. The resulting data enabled us to capture the comparative likelihood, at least theoretically, that a sample of multicultural teacher educators would incorporate into their MTE courses attention to a range of identities and oppressions, including those related to race, gender, sexual orientation, religion, disability, language, and class.

\section{CONTEXTUALIZING THIS STUDY}

A small body of existing scholarship details the relative invisibility of various identities and oppressions in multicultural education and MTE discourses (e.g., Duke, 2007; Johnson \& Nieto, 2007). Most work along these lines focuses on a single identity or oppression. Few attempts have been made to measure these discrepancies or to compare, in any detailed way, the relative presence of a variety of identity and oppression categories such as race, gender, sexual orientation, religion, language, and class, or intersections of these, in MTE contexts. Researchers who have conducted these studies have focused primarily on the relative presence of these concerns in MTE scholarship, such as journal articles and conference proceedings (Amosa \& Gorski, 2008; Furman, 2008; Gorski, 2010; Grant \& Gibson, 2011), rather than MTE practice. We found no scholarship analyzing the comparative extent or nature of attention to a variety of identities and oppressions in MTE coursework.

However, three stands of scholarship proved particularly useful in helping us ground this study: (1) the nature and equity implications of adopting a "hierarchy of oppression," (2) contested visions of multicultural education and the resulting implicit hierarchy of oppression in multicultural education theory and practice, and (3) intersectionality theory and the importance of engaging across identities and oppressions.

\section{The Nature and Implications of a Hierarchy of Oppression}

Individuals who adopt a "hierarchy of oppression" assume, or behave in ways that suggest an assumption, that some forms of oppression are more devastating than other forms of oppression (Lorde, 1983). Lorde (1984), in Sister Outsider, described how such an ideology forced her into an identity corner. She bemoaned the deleterious effects this experience had on her as a complex being, explaining that she was always "being encouraged to pluck out some aspect of myself and present this as the meaningful whole, eclipsing and denying the other parts of my self" (p. 120). These conditions, Lorde $(1983,1984)$ attested, constituted an additional layer of marginalization for the dispossessed, who are forced to disown the complexities of their identities.

McDonald and Coleman (1999), considering this layering of oppression, argued that adopting an ideological hierarchy of oppression means complying with the supremacist thinking of imperialist ideologies, implicitly supporting the relative marginalization of some groups in comparison with other groups. Endorsing a "multiple model" of oppression, they warned that hierarchies of oppression "encourage the notion that it is both possible and desirable to create hierarchies of humanity, and to measure human beings accordingly. These hierarchies are ultimately inconsistent, creating social divisions and stimulating social conflict between oppressed groups" (pp. 24-25). North (2010) agreed, insisting that disrupting one form of oppression while 
disregarding another form of oppression "is to maintain a willful public ignorance that actively reproduces social injustice" (p. 383).

Unfortunately, hierarchies of oppression often are more implicit than explicit, making them difficult to spot. Consider an example from multicultural education scholarship. Many multicultural education scholars focus exclusively on race in their scholarship without acknowledging that they are narrowing the focus. For instance, Gay (2005), in an article titled "Politics of Multicultural Teacher Education," described what she believed were the primary sociopolitical complexities of multicultural teacher education. She framed her article entirely around race but left her race-only conceptualization unacknowledged. She concluded, "Simply put, multicultural education in teacher preparation programs is conflicted" (p. 227) but missed the way in which its framing solely around race — not even acknowledging intersectionality between race and other identities - had been identified as one of the most potent conflicts in MTE (Marshall, 2009).

Complicating matters, often subhierarchies are formed within hierarchies of oppression. In rejecting a hierarchy of oppression within the disability rights movement, Tremain (1996) explained,

I do not draw the widely-accepted distinction between so called 'mental disability' and so called physical disability for two interdependent reasons: firstly, the distinction relies upon a philosophically indefensible mind/body dichotomy which prevails within traditional western epistemologies, where the mind and the body are construed as two separate entities, and the rational mind controls (that is, subordinates, and gives for to) the latter, construed as the irrational chaotic body; second, the way in which the mind is venerated in western epistemologies has not only resulted in numerous hierarchies in western cultures in general (for example, the prestige and power given to 'intellectual' labor as opposed to "physical" labor) but it has also produced a hierarchy within the disability community, and the movement in particular, where so called mentally disabled persons are regarded as "naturally impaired" and so called physically disabled persons are regarded as "socially disabled." (pp. 23-24)

By endorsing such a hierarchy, whether within or across identities and oppressions, scholars and practitioners run the risk of reifying the larger systems of inequity they mean, at least ostensibly, to redress. One such system involves the silo effect that impedes the unification of efforts toward the ideals of equity and social justice: the ideas that form the basis for multicultural education theory (Gorski, 2008; Nieto \& Bode, 2011). Freire (1996) warned of the implications of the silo effect, arguing that "oppressors halt by any means any action which in even incipient fashion could awaken the oppressed to the need for unity" (p. 122). The oppressor acts, in part, by creating "rifts" among the oppressed-the sorts of conditions Marshall (2009) warned were threatening the growth of multicultural education as a discipline and movement. Solanke (2009) illustrated this concern by pointing to the ways in which such rifts were created by, for instance, the Equal Protection Clause of the U.S. Constitution, which offers legal protections for some marginalized groups, but not for other groups.

\section{Contested Visions and the Implicit Hierarchy of Oppression in Multicultural Education}

Perhaps the worst case scenario for MTE courses-the lone opportunities afforded many teacher education candidates to engage with a range of equity concerns-would be for curricula to 
reflect these larger systems of inequity by supporting the notion of a hierarchy of oppression. Unfortunately, some scholars who have studied the visibility of a particular identity or oppression in MTE have argued that such a hierarchy already drives the MTE discourse (Fine \& McClelland, 2006; Gorski, 2010; Sapon-Shevin \& Zollers, 1999). For example, Quinn and Meiners (2011) and Blackburn and Smith (2010) found attention to lesbian, gay, bisexual, transgender, queer/questioning (LGBTQ) identities and oppressions in teacher education to be comparatively lacking. Johnson and McIntosh (2009) and Johnson and Nieto (2007) described the same phenomenon as it relates to disability.

In many cases, these scholars compared coverage of a particular identity or oppression to coverage of race and racism. For example, Blackburn and Smith (2010) noted that scholars focusing on the lives and experiences of queer people but not focusing on the lives and experiences of people of color are the targets of criticism about scholarship that privileges one dimension of difference over another difference. To be clear, none of the scholars who pointed to a hierarchy of oppression argued that race and racism ought not remain central in the theory and practice of MTE. Some scholars (e.g., Gorski, 2010; Marshall, 2009) explicitly acknowledged the sociohistorical conditions that have led to and sustained the centrality of race and racism in U.S. multicultural education discourses. Rather, most scholars argued that other identities and oppressions, and the ways in which those identities and oppressions interact with race and racism and with each other, also must become central concerns in multicultural education and MTE (Bell, Horn, \& Boxas, 2007; McLaren \& Farahmandpur, 2001).

According to the few studies that examined the coverage of a diversity of identities and oppressions in multicultural education and MTE discourses, scholars have good reason to raise concerns about the relative invisibility of several identities and oppressions and to note the dominance of race in these contexts. For instance, Amosa and Gorski (2008) analyzed the topics of session offerings at three successive annual conferences of the National Association for Multicultural Education (NAME), an association identified by a sample of more than 200 multicultural teacher-educators in a later study (Gorski, 2010) as the professional association that most influenced their MTE work. Amosa and Gorski (2008) found that, though more than one half of the NAME conference sessions focused on race and racism, $7.98 \%$ focused on gender and sexism, 5.46\% focused on class and economic injustice, and 3.78\% focused on disability and ableism. Similarly, based on an analysis of more than 150 researchbased articles, chapters, books, and reports on MTE, Grant and Gibson (2011) found that attention to a range of identities was distributed unequally. They discovered that 98 of the pieces of scholarship they analyzed addressed race and ethnicity, 51 addressed socioeconomic stratification, 37 addressed linguistic diversity, 22 addressed gender, 8 addressed disability, 6 addressed religion, and 1 addressed sexual orientation. Interestingly, Grant and Gibson (2011) did not problematize this distribution or discuss it in any way other than simply providing these percentages.

Further evidencing the centrality of race and relative invisibility of other identity and oppression concerns in MTE scholarship, Furman's (2008) analysis of seven syntheses of research on MTE uncovered 17 consistent themes. Race was named explicitly in two of these themes: (1) the lack of research on experiences of teachers of color and (2) a disproportionate focus on the experiences of White teacher candidates against relatively little attention to the experiences of teacher candidates of color. No other identity was named in any of the themes. Furman concluded, among other things, that, although researchers did not name this explicitly (in terms of 
how they conceptualized multicultural education), their research tended to be race-centric. He concluded,

Most reviews (and the studies included in them) address race significantly more than gender, class, linguistic diversity, national identity, religion, or other possible categories. Multiculturalism is largely assumed to be explicitly about race, or perhaps is too broadly or not clearly defined. (p. 60)

Speaking to the subhierarchy phenomenon (Tremain, 1996), some scholars have argued that MTE discourses have come to focus, not only on race, but more specifically on the identities and experiences of White teacher candidates (Chapman, 2011; Furman, 2008; Montecinos, 2004). Sleeter (2001) referred to this phenomenon as the "overwhelming presence of Whiteness" (p. 94) in MTE research. This narrowness of focus, in light of the absence of attention to teacher candidates of color, could suggest that, despite much of the scholarly attention to race-related identities and oppressions, MTE scholars and practitioners are struggling even to address race with much complexity (Chapman, 2011; Montecinos, 2004). Additionally, Lowenstein (2009) warned that the disproportionate focus in MTE research on the dispositions and experiences of White teacher candidates has resulted in widespread notions of White teacher candidates as deficit laden when it comes to understanding inequity. Meanwhile, it causes teacher educators to fail to take pedagogical advantage of White teacher candidates' understandings of the oppressions (i.e., sexism, heterosexism, economic injustice, ableism, linguicism) they might have experienced based on other dimensions of their identities. Such an approach also could discourage teacher educators and teacher candidates from considering intersections among various identities and oppressions (Reyes, Capella-Santa, \& Khisty, 1998).

Sometimes, the hierarchy of oppression in multicultural education and MTE is more implicit, evident not through explicit denunciation, but through quiet omission or underemphasis. The ongoing debate about the legitimacy of a hierarchy of oppression in MTE often is evident in implicit ways within single pieces of scholarship. For example, in a landmark set of studies resulting in a list of principles for best practice in MTE, Zeichner et al. (1998) argued that MTE ought to incorporate attention to a wide range of identities and oppressions. Interestingly, though, despite several instances in which the authors appeared to name broad swaths of identities and oppressions in descriptions of their "principles," they also regularly privileged race.

For example, introducing their design principle \#10, the authors stated, "The program helps prospective teachers reexamine their own and others' multiple and inter-related identities" (Zeichner et al., 1998, p. 168). The authors began their description of this principle by explaining that "every person has multiple identities that are formed through a unique and complex intersection of race, ethnicity, social class, gender, language, religion, sexual orientation, and ability" (p. 168). However, in the next paragraph they belied their own principle by suddenly singling out race. In that paragraph Zeichner et al. (1998) argued that during their teacher education programs, teacher candidates should learn about "the histories, contributions, and current status of various racial, ethnic, and cultural groups that comprise our society" (p. 168). Continuing, the authors explained, "This information should address both the variability within groups (avoiding group stereotyping) and common group characteristics (avoiding the idea of "color blindness")" (p. 168).

Similarly, Pang and Park (2011), in their proposal for a "new paradigm" for MTE, delineated five issues that they believed must be addressed in MTE. In their proposal they appeared 
careful to conceptualize "equity" inclusively, incorporating "race, culture, religion, class, gender, language, sexual orientation, and disabilities" (p. 64). However, the way that they operationalized this commitment in their list of "issues" belied this broad-based conceptualization. Under "issue four" in their model they stated that "the principle goal of multicultural teacher education must be to address the achievement gap between ethnic 'minority' students and their mainstream peers" (p. 65). No other identity group was mentioned. Additionally, they offered five questions to frame the conversation about a new paradigm for MTE. Race was the only identity named in their questions.

External influences may bolster the centrality of race and the relative lack of attention to other identities in MTE contexts. For example, the No Child Left Behind Act requires disaggregation of test score data across some identities, including race, but not across other identities, such as religion (Grant \& Gibson, 2011). Similarly, according to Quinn and Meiners (2007, 2011), by eliminating attention to sexual orientation in their standards, the National Council for the Accreditation of Teacher Education (NCATE) might have helped secure relative inattention to LGBTQ concerns in MTE. In addition, as Valenzuela (1999) pointed out, teacher candidates might enter MTE experiences already believing that race is central to conversations about multiculturalism.

Noting the dangers and limitations of a hierarchy of oppression, many prominent scholars have clarified that scholarship and practice in multicultural education and MTE ought to incorporate attention to a wide range of identities and oppressions, including identities and oppressions related to religion, race, gender, sexual orientation, disability, class, and language (Grant \& Sleeter, 2008; Ladson-Billings, 2011; Nieto \& Bode, 2011). Looking forward, Ladson-Billings (2011) instructed us to consider the possibility that dimensions of diversity beyond these six identities and oppressions may grow more salient in the future, as sociopolitical contexts in the United States and its schools continue to change. Still, according to Grant and Gibson (2011), debates persist over whose diversities ought to be accommodated in schools as well as whose oppressions should be considered, and to what degree, in multicultural education theory and practice.

Overall, our review of existing literature suggests that, at the very least, a hierarchy of oppression exists in MTE scholarship (Furman, 2008; Grant \& Gibson, 2011). However, prior to this study, little empirical attention had been paid to whether a similar hierarchy exists in MTE coursework.

\section{Intersectionality Theory Against a Hierarchy of Oppression}

According to intersectionality theory, oppression is rarely about only one form of difference (Bell et al., 2007). Individuals embody many identities, including intersectional identities, simultaneously. This dynamic, Stirratt, Meyer, Ouellette, and Gara (2007) explained, is the reason multicultural research and practice must account for these intersections. Bowleg (2008) added that identities are not additive, accumulating into a bigger and bigger single identity (e.g., "middle-class Latina woman with a disability"). Rather identities are intersectional, forming a complex and fluid identity, a point she made in the title of her essay, "When Black + Lesbian + Woman $\neq$ Black Lesbian Woman.” Ultimately, intersectionality theory, like other critical theories, necessarily rejects the notion of a hierarchy of oppression by insisting that we cannot understand any individual identity or oppression in a vacuum; we only can understand them as interlocking and interacting (North, 2010). 
Intersectionality theory interacts, itself, with other critical theories, some of which have influenced multicultural education theory and practice. For example, a central tenet of critical race theory is that racism only can be understood fully in its intersectionality with other forms of oppression, and that these oppressions "work together in disharmonious and irrational ways to form and challenge notions of homogeneity among racially marginalized groups" (Chapman, 2011, p. 241). Similarly, feminist and queer theories, particularly when layered with intersectionality theory, complicate understandings of patriarchy and heteronormativity (Cole, 2009) in their attention to the ways in which identities, oppressions, and liberation movements interact.

North (2010) described the cognitive benefits of intersectionality theory in relation to multicultural education theory and practice thusly:

When we stop reducing people to singular terms by, for example, learning about the lived experiences of people who identify as lesbian and Chicana, Jewish and gay, blind and bisexual, working-class and transgender, we can thicken our understandings of how individuals negotiate culture, gender, and power. (p. 382)

She clarified, though, that this "thickening" only can occur when we forego the sorts of additive or nonrelational identity paradigms that lend themselves to notions of a hierarchy of oppression and embrace those that are intersectional and relational.

\section{METHOD}

To ascertain the extent to which a hierarchy of oppression exists in U.S.-based MTE courses, we examined two sets of data: (1) a sample of detailed course schedules as codified in 41 syllabi from MTE courses taught across the United States, collected as part of a previous study of philosophical frameworks for MTE (Gorski, 2009); and (2) a survey $(N=122)$ of people who teach MTE courses in the United States about the topics and theoretical frameworks they are most likely to incorporate into their courses.

\section{Sample of MTE Syllabi}

Because the data collection and sampling methods used to accumulate the syllabi have been described in detail in previously published work (Gorski, 2009), we offer an abbreviated description of these elements and focus, instead, on how we used the data in this study.

In the previously published examination of these syllabi, 45 syllabi for MTE courses were collected from a regionally and institutionally diverse cross-section of education degree programs in the United States. An analysis of these syllabi, focusing primarily on course descriptions, objectives, and other indicators of explicit curricula (publicly named), supported McLaren's (1995) suggestion of three primary approaches to multiculturalism that he named conservative, liberal, and critical multiculturalism.

We wondered what we could learn about the visibility of a range of identity- and oppressionrelated concerns in MTE courses by examining another aspect of the syllabi: session-by-session course schedules, which were included in 41 of the syllabi. We used the session-by-session course schedules to calculate the average percentage of overall class time devoted to identity- or 
oppression-related topics, such as race, ethnicity, and racism; sex, gender, and sexism; and so forth. Then we calculated the percentage of these syllabi that omitted any mention of the same identity- or oppression-related topics. These calculations allowed us to consider the comparative prevalence of attention to race, gender, class, religion, language, and disability as codified on MTE syllabi.

\section{MTE Framework and Topic Survey}

A sample $(N=122)$ of people teaching MTE courses in education programs at U.S. colleges and universities was surveyed to identify how likely they were to incorporate various concepts (e.g., racial identity) and theoretical frameworks (e.g., critical race theory) into their MTE courses.

Sample. We employed an electronic form of snowball sampling. We sent electronic mail requesting participation to listservs frequented by people who teach MTE courses, including those hosted by Rethinking Schools, EdChange, and Division K (Teaching and Teacher Education) of the American Educational Research Association (AERA). To ensure the integrity of our data, we specified two conditions with which each participant had to conform: (1) having taught at least one course in the past 2 years in which the central topic was multicultural education, diversity education, social justice education, or a related topic (so that somebody who taught a course on a different topic, but who included a section on multicultural education, would not qualify) and (2) having taught such a course in an education program at a U.S. college or university and designed for, and taken predominantly by, current classroom teachers or teacher candidates.

A majority of our participants were female $(71.8 \%)$, whereas fewer participants were male $(28.2 \%)$. None of the participants identified her- or himself as transgender. A majority of the participants-70.9\% - were White or European American, whereas a smaller percent of participants-17.4\% - were Black, African, or African American; 7.0\% Latina/o, Chicana/o, or Hispanic, non-White; 4.7\% Asian, Asian American, or Pacific Islander; 2.3\% American Indian or Native American; and 2.3\% multiracial. None of the participants identified as Arab or Arab American, and $4.7 \%$ specified an alternative racial identity. More than three fourths $(76.7 \%)$ of the participants identified as heterosexual. Those participants who identified as lesbian made up $7.0 \%$, as did those participants who identified as bisexual. Gay men accounted for $4.7 \%$ of our sample, whereas $2.3 \%$ identified as questioning and $2.3 \%$ as queer. Full professors accounted for $11.6 \%$ of our sample, associate professors $22.1 \%$, assistant professors $39.5 \%$, instructors $16.3 \%$, and graduate teaching assistants $4.7 \%$. An additional $5.8 \%$ identified their faculty rank with a descriptor not included on our survey. When asked to identify their employment status, 30.2\% identified as full-time and tenured, $34.9 \%$ as full-time and tenure track, $15.1 \%$ as full-time and not tenure track, $15.1 \%$ as part-time or adjunct, and $4.7 \%$ as graduate students.

Instrument. In designing our survey, we drew upon our own expertise and experience in multicultural education and MTE, topics that appeared prevalently in Gorski's (2009) analysis of MTE syllabi, and recommendations and reviews by several experts in the field. We sought feedback on the instrument from six expert reviewers. After strengthening the instrument through their feedback, we pilot tested it with an additional six multicultural teacher educators.

It is important to note that identifying constructs across identities and oppressions proved challenging. Conceptions of identity- and oppression-related terms vary greatly. In addition, often 
parallel terms do not exist or are not common enough (as was the case with heterosexism just a couple decades ago), even among discipline-specific scholars, to allow for useful comparisons. We relied heavily on expert reviewers and pilot testers to help us refine terminology, and when disagreement about terms was more prevalent than agreement, we chose not to include language that might confuse participants. Instead, we used terms for which feedback was consistent enough for us to assume a considerable measure of shared understanding regarding their meaning.

This outcome created some holes in our data. For instance, we were unable to identity a term related to class that roughly paralleled hegemony-related terms commonly used in gender (patriarchy), sexual orientation (heteronormativity), and other identities. Suggestions were many and varied-capitalism, consumer culture, corporatocracy — and none garnered much agreement among our expert reviewers and pilot testers. As a result, we decided not to include any of these constructs on the survey.

Data analysis. Participants $(N=122)$ were asked to rate the likelihood that they would incorporate 23 different constructs into their MTE course(s) as shown in Table 1.

Each of the 23 constructs was scored on a 5-point Likert-type scale from 1 (extremely unlikely) to 5 (extremely likely). One-sample $t$ tests were used to determine whether the mean likelihoods for the constructs "Racial Identity," "Racism," "White Privilege," and "Critical Race Theory" were different from the mean likelihoods for the other constructs. We chose to compare against

TABLE 1

Constructs Included on the Survey of People Teaching Multicultural Teacher Education Courses

\begin{tabular}{ll}
\hline Dimension of Identity or Oppression & \multicolumn{1}{c}{ Constructs } \\
\hline Race & Racial identity \\
& Racism \\
& White privilege \\
& Critical race theory \\
Sexual orientation & Sexual orientation \\
& Homophobia \\
& Heterosexism \\
& Heteronormativity \\
& Queer theory \\
& Gender identity \\
Gender & Sexism \\
& Male privilege \\
& Patriarchy \\
& Feminist theory \\
& Socioeconomic class identity \\
Class & Poverty \\
& Classism \\
Religion & Economic injustice \\
& Religious or faith identity \\
& Religious oppression \\
& Christian hegemony \\
& Disability \\
& Ableism \\
\hline
\end{tabular}


race-related constructs based on our review of MTE literature, which suggested that race-related concerns tend to dominate discourses related to multicultural education (Blackburn \& Smith, 2010; Marshall, 2009).

This process enabled us, by drawing on Gorski's (2009) expansion of McLaren's (1995) typology of approaches to MTE, to compare and mean likelihoods across a range of concepts and theoretical frameworks-identity descriptors (e.g., gender identity), forms of oppression (e.g., sexism), critical theoretical frameworks (e.g., feminist theory) - to determine the nature of the relative inclusion across them. This decision, in turn, provided contour to our analysis, allowing us to compare likelihoods of concept and framework incorporation on a continuum captured by McLaren's (1995) and Gorski's (2009) approaches to addressing multicultural concerns:

1. a conservative approach to MTE, characterized by a focus on identity (e.g., sexual orientation) and individual bias

2. a liberal approach, characterized by a focus on identity and oppression

3. a critical approach, characterized by a focus on the relationships between identity, oppression, and counter-hegemonic practice within the larger sociopolitical contexts described by critical theories.

Based on this continuum, we examined, for instance, the likelihood participants would engage a critical approach to LGBTQ concerns with the likelihood they would engage a critical approach to race.

The analyses were conducted using PASW Statistics v.18 (SPSS) and pairwise deletion was used for missing values. A significance level of alpha $=.05$ was used for all tests.

\section{FINDINGS}

In this section we summarize our findings, beginning with findings from the course schedule analysis and then findings from the survey before considering the data together.

\section{The Official Curriculum of MTE: Course Schedule Analysis}

Tables 2 and 3 summarize the findings from our analysis of 41 MTE course syllabi regarding the comparative prevalence of class time devoted, as codified in the syllabi, to content focused on a range of identity and oppression constructs.

According to syllabi course schedules concerns related to race and racism received considerably more attention in the MTE courses examined than did any other identity or oppression concerns. On average, multicultural teacher educators devoted nearly 3 times as much class time to race as to gender, the next most prevalent concern. They devoted nearly 6 times as much time to race and twice as much time to gender as to class, sexual orientation, or language.

Similarly, according to the overall text on the syllabi, MTE faculty were nearly 7 times more likely to omit gender concerns fully from syllabi (from an official or stated curriculum point of view) than they were to omit race concerns. Nearly one third of the syllabi were silent on gender, and percentages increased for sexual orientation, class, language, disability, and religion. As with class time, race appeared most prominently. Gender lagged significantly behind race but received considerably more than a cluster of other concerns, such as sexual orientation and class. It is 
TABLE 2

Average Percentage of Class Time Devoted to Specific Identities and Oppressions According to Class Schedules Embedded in Multicultural Education Course Syllabi

\section{Dimension of Identity or Oppression}

Race (racism, racial identity, white privilege, critical race theory, etc.)

Gender (sexism, gender identity, transgender identity, feminist theory, etc.)

Sexual orientation (heterosexism, homophobia, LGBTQ identities, queer theory, etc.)

Class/Socioeconomic Status (classism, poverty, economic injustice, class identity, etc.)

Language (linguicism, ELL identity, etc.)

Disability (ableism, ability identity, critical disability theory, etc.)

Religion, faith, and spirituality (religious oppression, Islamophobia, religious or non-religious identity, etc.)
Average Percent of Overall Class Time Devoted

LGBTQ = lesbian, gay, bisexual, transgender, queer/questioning; ELL = English language learner. Note. $N=41$

${ }^{a}$ Approximately 9.8 hours of a 45 -hour class.

${ }^{\mathrm{b}}$ Approximately 52 minutes of a 45-hour class.

TABLE 3

Percentage of Syllabi Containing No Mention of Specific Identity- or Oppression-Related Concerns in Any Form

\begin{tabular}{lc}
\hline Dimension of Identity or Oppression & $\begin{array}{c}\text { Percent of Syllabi in Which } \\
\text { Dimension is Omitted }\end{array}$ \\
\hline Race & 4.80 \\
Gender & 32.71 \\
Sexual and affectional orientation & 41.46 \\
Class/Socioeconomic status & 53.66 \\
Language & 56.10 \\
Disability & 63.41 \\
Religion & 70.73 \\
\hline
\end{tabular}

$N=41$.

notable, as well, that none of these 41 syllabi addressed intersectional concerns among two or more identities.

Although these findings supported existing scholarship hinting at the existence of a hierarchy of oppression in MTE (Blackburn \& Smith, 2010; Gorski, 2010; Marshall, 2009), they left important questions unanswered. For example, some faculty who intend to teach about heterosexism might choose strategically to omit such language from their syllabi to move it successfully through a curriculum review process. The syllabi painted an important picture of the official or stated curriculum of MTE-after all, the omission from syllabi has its own implicit implications even if it is conducted strategically_but we could not be completely sure that MTE faculty did not teach about particular constructs or concepts just because they did not appear on course syllabi. 


\section{Likelihood of Incorporation of Identity and Oppression Concerns: The Survey}

Table 4 summarizes the comparative likelihood that multicultural education educators would incorporate various identity- and oppression-related constructs into their courses. Participants were most likely to incorporate attention to racism and White privilege-both race-related constructs-into their courses than any of the other constructs. In an unexpected finding, onesample $t$ tests showed, though, that the likelihood of the participants incorporating classism was not statistically significantly lower than that of incorporating racism $(X=4.68)$ or White privilege $(\mathrm{X}=4.64)$ and their likelihood of incorporating poverty did not differ significantly from White privilege.

We also examined parallel concepts across identities and oppressions, including identity constructs (gender identity, sexual orientation), forms of oppression (sexism, heterosexism), hegemonies (patriarchy, heteronormativity), and critical theoretical frameworks (feminist theory,

TABLE 4

Mean Values for Respondents' Likelihood of Inclusion of Concepts into Multicultural Teacher Education Courses

\begin{tabular}{ll}
\hline Concept & Mean \\
\hline Racial identity & $3.90^{\mathrm{b}, \mathrm{c}}$ \\
Racism & $4.68^{\mathrm{a}, \mathrm{d}}$ \\
White privilege & $4.64^{\mathrm{a}, \mathrm{d}}$ \\
Critical race theory & $3.80^{\mathrm{b}, \mathrm{c}}$ \\
Sexual orientation & $4.12^{\mathrm{a}, \mathrm{b}, \mathrm{c}, \mathrm{d}}$ \\
Homophobia & $4.03^{\mathrm{a}, \mathrm{b}, \mathrm{c}, \mathrm{d}}$ \\
Heterosexism & $4.05^{\mathrm{b}, \mathrm{c}, \mathrm{d}}$ \\
Heteronormativity & $3.64^{\mathrm{a}, \mathrm{b}, \mathrm{c}}$ \\
Queer theory & $2.99^{\mathrm{a}, \mathrm{b}, \mathrm{c}, \mathrm{d}}$ \\
Gender identity & $3.59^{\mathrm{a}, \mathrm{b}, \mathrm{c}}$ \\
Sexism & $4.32^{\mathrm{a}, \mathrm{b}, \mathrm{c}, \mathrm{d}}$ \\
Male privilege & $4.01^{\mathrm{b}, \mathrm{c}}$ \\
Patriarchy & $3.57^{\mathrm{a}, \mathrm{b}, \mathrm{c}}$ \\
Feminist theory & $3.30^{\mathrm{a}, \mathrm{b}, \mathrm{c}, \mathrm{d}}$ \\
Socioeconomic class identity & $4.35^{\mathrm{a}, \mathrm{b}, \mathrm{c}, \mathrm{d}}$ \\
Poverty & $4.49^{\mathrm{a}, \mathrm{b}, \mathrm{d}}$ \\
Classism & $4.53^{\mathrm{a}, \mathrm{d}}$ \\
Economic injustice & $4.38^{\mathrm{a}, \mathrm{b}, \mathrm{c}, \mathrm{d}}$ \\
Religious or faith identity & $3.41^{\mathrm{a}, \mathrm{b}, \mathrm{c}, \mathrm{d}}$ \\
Religious oppression & $3.41^{\mathrm{a}, \mathrm{b}, \mathrm{c}, \mathrm{d}}$ \\
Christian hegemony & $3.43^{\mathrm{a}, \mathrm{b}, \mathrm{c}, \mathrm{d}}$ \\
Disability & $3.94^{\mathrm{b}, \mathrm{c}}$ \\
Ableism & $3.91^{\mathrm{b}, \mathrm{c}}$ \\
\hline
\end{tabular}

$N=122$.

$1=$ extremely unlikely to $5=$ extremely likely.

${ }^{a}$ Significantly different from racial identity.

${ }^{\mathrm{b}}$ Significantly different from racism.

${ }^{\mathrm{c}}$ Significantly different from White privilege.

${ }^{\mathrm{d}}$ Significantly different from critical race theory.

$p<0.05$ for $t$ tests. 
queer theory) to uncover the nature of comparative incorporation of these constructs into MTE courses.

In terms of identity constructs, participants were significantly more likely to incorporate sexual orientation, socioeconomic class identity, and disability and significantly less likely to incorporate gender identity and religious or faith identity than racial identity. Regarding forms of oppression, participants were statistically significantly more likely to incorporate racism than oppression constructs related to any of the other identifiers. When it came to hegemonies, participants were significantly more likely to incorporate White privilege than heteronormativity, patriarchy, or Christian hegemony. Participants similarly were more likely to incorporate critical race theory than critical theories springing from scholarly and activist traditions related to sexual orientation (queer theory) or gender (feminist theory).

Applying Gorski's (2009) typology of approaches to MTE, adapted from McLaren's (1995) approaches to multiculturalism, these findings suggest that, although participants might have been more likely to incorporate attention to constructs related to some other identities (e.g., sexual orientation, class identity) at the conservative multiculturalism level (focused on identity, but not oppression or sociopolitical context), the participants consistently were more likely to incorporate race and class constructs at the liberal level (focused on oppression, but not necessarily sociopolitical context or social action) and race constructs at the critical level (focused on sociopolitical context and social action, as through the lens of critical theories) than those constructs related to other identities or oppressions.

Of interest, as well, is the lack of drop-off between patterns of incorporation between racerelated oppression (racism) and hegemonic (White privilege) constructs that appears to exist in relation to sexual orientation and gender (the only other categories for which relatively parallel constructs were identified). Moreover, the only two constructs whose pattern of incorporation did not significantly pale in comparison with racism and White privilege were poverty and classisma surprising finding considering that the course schedule analysis suggested a considerable pattern of inattention, if not outright omission, of class concerns from the official curriculum of U.S.based MTE courses.

\section{DISCUSSION}

Our findings largely confirmed existing scholarship on the existence of a hierarchy of oppression in MTE theory and practice. However, several factors made our findings unique. First, although other studies had found a hierarchy of oppression in MTE scholarship (Furman, 2008; Gorski, 2010; Grant \& Gibson, 2011), we identified the same phenomenon within MTE coursework, which constitutes, for many classroom teachers and teacher candidates, the sole formal opportunity to explore equity concerns (Cochran-Smith, 2003; Scott \& Ford, 2010). Second, although there existed several studies that examined the relative coverage of a particular identity or oppression in MTE practice (Duke, 2007; Johnson \& Nieto, 2007), heretofore there had been little opportunity to describe a fuller hierarchy of oppression across more than one or two identities or oppressions. Our findings allowed us to begin to describe the hierarchy of oppression in MTE coursework, not just between race and one other identity, but among race, gender, sexual orientation, class, and disability. Third, we were able to identify interesting contradictions between the official or stated curriculum of MTE courses (as codified in syllabi) and course instructors' 
claims about what they cover in practice. Upon discussing each of these three themes in greater detail and their implications, we offer an argument, drawing on intersectionality theory, for more concerted efforts by MTE theorists and practitioners to eliminate the hierarchy of oppression in MTE coursework.

\section{The Hierarchy of Oppression in MTE Coursework}

Taken together, our analyses suggest that racial identities and oppressions receive more attention in U.S.-based MTE courses than any other identity or oppression concern we examined. A hierarchy of oppression does, indeed, exist in U.S. MTE courses, and it appears as though race occupies the top of the oppression pyramid. This analysis, again, is consistent with scholarship describing similar phenomena in multicultural education conferences (Amosa \& Gorski, 2008) and scholarship (Gorski, 2010; Grant \& Gibson, 2011).

In addition to garnering more attention than other identities and oppressions overall, we found that race-related constructs tend to receive more critical considerations, generally speaking, than those related to gender, sexual orientation, class, religion, or disability. For example, although multicultural teacher educators were more likely to incorporate sexual orientation than race at the conservative (Gorski, 2009; McLaren, 1995) level, teacher educators were significantly less likely to incorporate it at the liberal or critical levels. Even in the case of class concerns, for which participants were not significantly less likely to incorporate a liberal framework (classism) than they were for race (racism), teacher educators were significantly less likely to incorporate a critical framing when it came to class.

Although our methods for analyzing the survey data did not enable us to envision what the rest of the hierarchy looked like with much precision, our analysis of MTE course schedules helped us paint a somewhat more nuanced picture. Interestingly, though, there were ways in which the analyses revealed inconsistent results. According to our analysis of course schedules, gender-related identities and oppressions garnered nearly twice the attention (as codified in course syllabi) as sexual orientation or class. The survey data, however, were less conclusive about this relationship. Drawing just on general patterns of time commitment and omission as codified in syllabi-in other words, on the official curriculum of MTE - it appears as though, following race, gender occupies the highest position in the MTE hierarchy of oppression, followed by a group of identities and oppressions including those related to sexual orientation, class, and language, with disability and religion make up the bottom of the hierarchy.

These sorts of patterns - the relative (in)visibility of specific identities and oppressions in MTE — have been tracked before (Johnson \& Nieto, 2007). Scholars previously have called for increased attention in MTE to, among other identities and oppressions, those related to sexual orientation (Blackburn \& Smith, 2010; Quinn \& Meiners, 2011), disability (Johnson \& McIntosh, 2009), and class (McLaren \& Farahmandpur, 2001). Still, the question of whether MTE theory and practice ought to be more inclusive remains contested, even within NAME, the largest multicultural education professional association in the United States (Marshall, 2009). The contested nature of this dilemma also is evident, if much more implicitly so, in the history of MTE scholarship, much of which centers race and renders other multicultural concerns relatively invisible, sometimes even on occasions when scholars initially suggest a broad vision for multicultural education (Furman, 2008). 
Intersectionality theory, emerging from a long tradition of Black feminist scholarship and activism, provides a set of tools for examining hierarchies of oppression and their implications. The notion of intersectionality holds that oppression rarely is about a single form of difference (Bell et al., 2007), that each of us embodies many intersecting identities simultaneously (Stirrat et al., 2007), and that these identities form a complex and fluid web rather than an additive list of single identities (Bowleg, 2008). As a result, just as Lorde (1983) refused attempts to force her to choose in any given moment whether she was Black, a lesbian, or a woman, all such attempts to pull a singular, decontextualized identity out of the complex web of a person's being must be rejected.

This situation is a matter of principle; nobody can decide for somebody else what is most salient to her or him in a given moment. But it also is a matter of complex understanding. After all, as Lorde (1983) clarified so eloquently, no identity or oppression can be understood with any complexity in a vacuum; they only can be understood as intersectional (North, 2010).

We must incorporate gender into MTE experiences because gender is important in its own right (Montecinos \& Nielsen, 2004) and because we cannot even understand race, sexual orientation, disability, class, or language without also understanding gendered identities and experiences and how they interact with other identities. We must incorporate disability (Cole, 2009) because disability is important in its own right, but also because we cannot understand oppressive educational practices, such as the overreferral of low-income boys of color to special education (Scott \& Ford, 2011), without understanding the web created by ableism, economic injustice, and a host of other oppressions. The same can be said of language and linguicism (Bernhard, Diaz, \& Allgood, 2005; Uys, Reyneke, \& Kaiser, 2011) and class and economic injustice (McLaren \& Farahmandpur, 2001).

A failure to attend to intersectionalities, a process that requires the desertion of any notion of a hierarchy of oppression, only can result in the proliferation of injustice. For instance, hooks (1981) warned of "horizontal hostility" as one implication of the institutionalization of a nonintersectional hierarchy of oppression. Horizontal hostility describes conditions whereby one disenfranchised community (low-income Christian teacher candidates, for instance), which has experienced one or more forms of disadvantage, are encouraged within hegemonic contexts (such as their places of worship) to blame another disenfranchised community (LGBTQ people, for example) for societal problems. The "hostility" or "scornful gaze" (Gorski, 2011) is pointed horizontally or down rather than up the power hierarchy. We risk replicating these sorts of conditions when MTE theory and practice reflect a hierarchy of oppression.

\section{Eliminating the Hierarchy of Oppression from MTE Coursework}

In the end, as intersectionality theory suggests, we believe that the relative inattention to a variety of identities and oppressions in MTE necessarily limits even the extent to which classroom teachers and teacher candidates are able to understand the complexities of race and racism. Following Lorde's (1983) argument, if I do not learn to be an antisexist educator, I cannot really be an effective antiracist educator, because approximately one half of people of color are women; if I do not learn to be an antiheterosexist educator, I cannot be an effective antiracist or antisexist educator, because many people of color and women identify as LGBTQ. And so, understanding the complications inherent in our position, we argue based upon intersectionality theory that 
the only just course-and, in the end, the only course that will help us prepare teachers to practice antiracism education-is to eliminate the hierarchy of oppression in MTE, including MTE coursework.

To be clear, we do not argue for less attention to race and racism in MTE scholarship or coursework. We do not argue that every bit of attention historically and presently focused on race and racism in MTE and other contexts is unwarranted. Indeed, much of our own scholarship has focused on racial justice and its intersections with class and gender justice. Rather, we argue for greater attention to gender, sexual orientation, class, religion, language, and disability and, even more than these constructs, to intersectionalities among as well as within (as, for instance, with multiracial identities and experiences) a broader range of identities and oppressions.

We understand, of course, and have grappled with the implications of time limitations. The request that multicultural teacher educators squeeze learning experiences about all equity concerns into one course is unreasonable. Some teacher educators have argued that it reflects a purposeful assurance of limited attention to these concerns and a purposeful disintegration of equity concerns from education theory and practice (Keiser, 2005; Sleeter, 2008). According to a study on multicultural teacher educators' perceptions the most common challenges faced in MTE practice (Gorski, in press), multicultural teacher educators are extremely concerned about time constraints and the implications of having to exclude important content from their courses.

Additionally, many people teaching MTE courses are located in environments where teaching about some concerns, such as queer rights, is met with hostility from colleagues (Cosier \& Sanders, 2007) and teacher candidates (Asher, 2007), imposing additional pressure to refrain from incorporating particular topics into their courses, at least explicitly. What would be extremely helpful, and perhaps an important new direction for intersectionality theorists, would be the development of intersectionality pedagogy, characterized by a theoretical commitment to intersectionality and a set of tools and principles for how to teach about social justice concerns in an intersectional manner. Other critical theories and pedagogies - most notably, queer theory and pedagogy — provide some theoretical guidelines for such a pursuit. Thus, we encourage our MTE colleagues to engage more deeply with queer theory as one point of departure. Unfortunately, previous research (Gorski, 2010) has demonstrated that instructors responsible for teaching MTE courses report fairly little engagement with scholarship (books, magazines, and journals) addressing sexual orientation in any form, and that this pattern holds true for class, religion, disability, and language, as well.

We also call on professional organizations that count among their memberships large numbers of people who teach MTE courses to examine the hierarchy of oppression reflected in their publications, conferences, and other forums. A previous study (Amosa \& Gorski, 2008) uncovered such a hierarchy, for instance, in the sessions offered at NAME's national conference. We encourage NAME to develop processes, not only for seeking sessions that speak to a more inclusive variety of identities and oppressions but also for seeking speakers who discuss intersectionalities. Similarly, we encourage the publication, Rethinking Schools, whose publication was identified in a previous study of instructors responsible for teaching MTE courses (Gorski, 2010) as the magazine or journal which was "most influential" to their MTE work, and other magazines and journals read prominently by multicultural teacher educators to be more attentive to intersectionalities and the identities and oppressions that historically have received, and continue to receive, relatively little attention in multicultural discourses. 


\section{Limitations and Future Directions}

Several limitations to this study should be noted. Although our analysis of syllabi allowed us to consider the official curriculum of MTE, syllabi do not necessarily paint an accurate picture of the explicit curriculum (that which is explicitly taught) or implicit curriculum (that which is learned implicitly) of the courses they represent. Similarly, not all faculty have full autonomy over their syllabi. Some MTE faculty may incorporate content into their courses that was not codified in syllabi. Conversely, some faculty might have chosen not to address certain issues despite their presence on syllabi. Our inability to know the extent of either scenario made the results of that part of our analysis inexact. It is important to note, as well, that, although research (Gorski, 2009) has shown that most MTE courses and, as a result, most MTE syllabil are organized by identity or oppression ("this week we're studying race; next week we're studying gender") we noted, for example, that 36 of the 41 syllabi in our sample were organized thusly-not all MTE courses are organized in this way, which might have made the incorporation of identityand oppression-related concerns less explicit, even if they were incorporated into conversations about, for instance, curriculum development or classroom management.

Finally, textual analysis requires interpretation. Our inability to know how those who constructed the syllabi conceptualized the content listed on them, and our inability to know how the faculty teaching the courses operationalized this content, limited the preciseness with which we could calculate the prevalence of various equity-related concerns. Future research might complicate this analysis by examining readings, major assignments, and other aspects of MTE courses to more precisely uncover the visibility and nature of attention to a full range of identities and oppressions in them.

\section{CONCLUSION}

“There is no hierarchy of oppression," Audre Lorde insisted in 1983. Or at least there ought not be, intersectionality theorists more recently have argued. Unfortunately, in this study, we found evidence supporting previous scholarship that a hierarchy of oppression does exist in MTE. Unlike previous scholarship, we found such a hierarchy in MTE coursework, a particularly meaningful finding in the sense that, for many educators, a single MTE course represents the lone opportunity to examine equity and social justice concerns during formal teacher preparation processes.

Given the results of previous studies on the hierarchy of oppression in other MTE contexts and the place of race and racism in the sociohistory of the United States, it was little surprise to find race-related identities and oppressions atop the hierarchy of oppression in MTE coursework, in terms of likelihood and amount of coverage and in terms of the depth or criticality of coverage. Although it is difficult after this single study to discern a precise pattern of identities and oppressions after race, it appears as though the middle of the hierarchy comprises a combination of gender, class, and sexual orientation concerns whereas religion, disability, and language fall somewhere toward the bottom. Intersectionality theory and the critical theories from which it arose provided a framework for describing the dangers inherent in the discrepancies in coverage of these concerns. 
These findings raised a variety of questions pointing to possibilities for further examination of the hierarchy of oppression in MTE. Qualitative methods involving interviews or focus groups with multicultural teacher educators might help uncover with greater detail the philosophical nature of the hierarchy and why it exists from the perspectives of those who teach MTE courses. Further examination could be conducted on the implications of the hierarchy by capturing their influence on the knowledge bases, dispositions, and practices of classroom teachers and teacher candidates who participated in MTE coursework in which the hierarchy was more or less apparent. Additionally, future research might explore possibilities for the employment of intersectionality theory in MTE, especially when most teacher candidates may come to their MTE classes with nonintersectional understandings of identities and oppressions.

\section{REFERENCES}

Amosa, W., \& Gorski, P. C. (2008). Directions and mis-directions in multicultural education: An analysis of session offerings at the annual conference of the National Association for Multicultural Education. Multicultural Perspectives, 10(3), 167-174.

Asher, N. (2007). Made in the (multicultural) USA: Unpacking tensions of race, culture, gender, and sexuality in education. Educational Researcher, 36(2), 65-73.

Banks, J. (2010). Multicultural education: Characteristics and goals. In J. Banks \& C. Banks (Eds.), Multicultural education: Issues and perspectives (pp. 3-29). Hoboken, NJ: Wiley.

Bell, C. A., Horn, B. R., \& Roxas, K. C. (2007). We know it's service, but what are they learning? Preservice teachers' understandings of diversity. Equity \& Excellence in Education, 40(2), 123-133.

Bernhard, J. K., Diaz, C. F., \& Allgood, I. (2005). Research-based teacher education for multicultural contexts. Intercultural Education, 16(3), 263-277.

Blackburn, M. V., \& Smith, J. M. (2010). Moving beyond the inclusion of LGBT-themed literature in English Language Arts classrooms: Interrogating heteronormativity and exploring intersectionality. Journal of Adolescent and Adult Literacy, 53(8), 625-634.

Bowleg, L. (2008). When Black + lesbian + woman $\neq$ Black lesbian woman: The methodological challenges of qualitative and quantitative intersectionality research. Sex Roles, 59(5/6), 312-325.

Chapman, T. K. (2011). A critical race theory analysis of past and present institutional processes and polices in teacher education. In A. F. Ball \& C. A. Tyson (Eds.), Studying diversity in teacher education (pp. 237-256). New York, NY: Rowman \& Littlefield.

Clark, C. T. (2010). Preparing LGBTQ-allies and combating homophobia in a U.S. teacher education program. Teaching and Teacher Education, 26(3), 704-713.

Cochran-Smith, M. (2003). The multiple meanings of multicultural teacher education: A conceptual framework. Teacher Education Quarterly, 30(2), 7-26.

Cole, B. A. (2009). Gender, narratives and intersectionality: Can personal experience approaches to research contribute to "undoing gender"? International Review of Education, 55(5/6), 561-578.

Cosier, K., \& Sanders, J. H. (2007). Queering art teacher education. International Journal of Art \& Design Education, 26(1), 21-30.

Davidman, L., \& Davidman, P. (1997). Teaching with a multicultural perspective: A practical guide. New York, NY: Longman.

Duke, T. (2007). Hidden, invisible, marginalized, and ignored: A critical review of the professional and empirical literature (or lack thereof) on gay and lesbian teachers in the United States. Journal of Gay \& Lesbian Issues in Education, 4(4), 19-38.

Fine, M., \& McClelland, S. (2006). Sexuality education and desire: Still missing after all these years. Harvard Educational Review, 76(3), 297-338.

Freire, P. (1996). Pedagogy of the oppressed. London, UK: Penguin.

Furman, J. S. (2008). Tensions in multicultural teacher education research: Demographics and the need to demonstrate effectiveness. Education and Urban Society, 41(1), 55-79. 
Gay, G. (2005). Politics of multicultural teacher education. Journal of Teacher Education, 56(3), 221-228.

Gorski, P. C. (2006). Complicity with conservatism: The de-politicizing of multicultural and intercultural education. Intercultural Education, 17(2), 163-177.

Gorski, P. C. (2008). Good intentions are not enough: A decolonizing intercultural education. Intercultural Education, 19(5), 515-525.

Gorski, P. C. (2009). What we're teaching teachers: An analysis of multicultural education coursework syllabi. Teaching and Teacher Education, 25(2), 309-318.

Gorski, P. C. (2010). The scholarship informing the practice: Multicultural teacher education philosophy and practice in the U.S. International Journal of Multicultural Education, 12(2). Retrieved from http://ijme-journal.org/index.php/ ijme/article/view/352/513

Gorski, P. C. (2011). Unlearning deficit ideology and the scornful gaze: Thoughts on authenticating the class discourse in education. In R. Ahlquist, P. C. Gorski, \& T. Montaño (Eds.), Assault on kids: How hyper-accountability, corporatization, deficit ideologies, and Ruby Payne are destroying our schools (pp. 152-176). New York, NY: Peter Lang.

Gorski, P. C. (in press). Instructional, institutional, and sociopolitical challenges of teaching multicultural teacher education courses. Teacher Educator.

Grant, C., \& Gibson, M. (2011). Diversity and teacher education: A historical perspective on research and policy. In A. F. Ball \& C. A. Tyson (Eds.), Studying diversity in teacher education, (pp. 19-61). New York, NY: Rowman \& Littlefield.

Grant, C., \& Sleeter, C. (2008). Turning on learning: Five approaches to multicultural teaching plans for race, class, gender, and disability. Upper Saddle River, NJ: Prentice Hall.

hooks, b. (1981). Ain't I a woman? Black women and feminism. Boston, MA: South End Press.

Johnson, J. R., \& McIntosh, A. S. (2009). Toward a cultural perspective and understanding of the disability and deaf experience in special and multicultural education. Remedial and Special Education, 30(2), 67-83.

Johnson, J. R., \& Nieto, J. (2007). Toward a cultural understanding of the disability and deaf experience: Implications of a content analysis of introductory special education and multicultural education textbooks. Multicultural Perspectives, 9(4), 32-39.

Keiser, D. L. (2005). Learners not widgets: Teacher education for social justice during transformative times. In N. M. Michelli \& D. L. Keiser (Eds.), Teacher education for democracy and social justice (pp. 31-55). New York, NY: Routledge.

Kumashiro, K. (2008). The seduction of common sense: How the right has framed the debate on America's schools. New York, NY: Teachers College Press.

Ladson-Billings, G. (2011). Asking the right questions: A research agenda for studying diversity in teacher education. In A. F. Ball \& C. A. Tyson (Eds.), Studying diversity in teacher education (pp. 385-398). New York, NY: Rowman \& Littlefield.

Lorde, A. (1983). There is no hierarchy of oppressions. Bulletin: Homophobia and Education, 14(3/4), 9.

Lorde, A. (1984). Sister outsider: Essays and Speeches. Trumansberg, NY: Crossing Press.

Lowenstein, K. L. (2009). The work of multicultural teacher education: Reconceptualizing White teacher candidates as learners. Review of Educational Research, 79(1), 163-196.

Marshall, P. L. (2009). Multicultural education in a post-race political age: Our movement at risk? Multicultural Perspectives, 11(4), 188-193.

McDonald, P., \& Coleman, M. (1999). Deconstructing hierarchies of oppression and adopting a "multiple model" approach to anti-oppressive practice. Social Work Education, 18(1), 19-34.

McLaren, P. (1995). White terror and oppositional agency: Toward a critical multiculturalism. In C. E. Sleeter \& P. McLaren (Eds.), Multicultural education, critical pedagogy, and the politics of difference (pp. 33-70). Albany, NY: State University of New York Press.

McLaren, P., \& Farahmandpur, R. (2001). Class, cultism, and multiculturalism: A notebook on forging revolutionary politics. Multicultural Education, 8(3), 2-14.

Montecinos, C. (2004). Paradoxes in multicultural teacher education research: Students of color positioned as objects while ignored as subjects. International Journal of Qualitative Studies in Education, 17(2), 167-181.

Montecinos, C., \& Nielsen, L. E. (2004). Male elementary preservice teachers' gendering of teaching. Multicultural Perspectives, 6(2), 3-9.

Nakano Glenn, E. (1999). The social construction and institutionalization of gender and race: An integrative framework. In M. M. Feree, J. Lorber, \& B. B. Hess (Eds.), Revisioning gender (pp. 3-43). Thousand Oaks, CA: Sage. 
Nieto, S., \& Bode, P. (2011). Affirming diversity: The sociopolitical context of multicultural education. New York, NY: Longman.

North, C. E. (2010). Threading stitches to approach gender identity, sexual identity, and difference. Equity \& Excellence in Education, 43(3), 375-387.

Pang, V. O., \& Park, C. D. (2011). Creating interdisciplinary multicultural teacher education. In A. F. Ball \& C. A. Tyson (Eds.), Studying diversity in teacher education (pp. 63-80). New York, NY: Rowman \& Littlefield.

Quinn, T., \& Meiners, E. R. (2007). Do ask, do tell: What's 'professional' about taking social justice and sexual orientation out of public school classrooms? Rethinking Schools, 21(4), 25-26.

Quinn, T., \& Meiners, E. R. (2011). Teacher education, struggles for social justice, and the historical erasure of lesbian, gay, bisexual, transgender, and queer lives. In A. F. Ball \& C. A. Tyson (Eds.), Studying diversity in teacher education (pp. 135-151). New York, NY: Rowman \& Littlefield.

Reyes, S., Capella-Santana, N., \& Khisty, L. L. (1998). Prospective teachers constructing their own knowledge in multicultural education. In M. Dilworth (Ed.), Being responsive to cultural differences: How teachers learn (pp. 110-125). Thousand Oaks, CA: Corwin Press.

Risman, B. J. (2004). Gender as a social structure: theory wrestling with activism. Gender \& Society, 18(4), 429-450.

Rivière, D. (2005). Identities and intersectionalities: Performance, power, and the possibilities for multicultural education. Research in Drama Education, 10(3), 341-354.

Sapon-Shevin, M., \& Zollers, N. J. (1999). Multicultural and disability agendas in teacher education: Preparing teachers for diversity. International Journal of Leadership in Education, 3(2), 165-190.

Scott, M. T., \& Ford, D. Y. (2011). Preparing teacher education candidates to work with students with disabilities and gifts and talents. In A. F. Ball \& C. A. Tyson (Eds.), Studying diversity in teacher education (pp. 201-217). New York, NY: Rowman \& Littlefield.

Shields, S. A. (2008). Gender: An intersectionality perspective. Sex Roles, 59(5/6), 301-311.

Sleeter, C. E. (2001). Preparing teachers for culturally diverse schools: Research and the overwhelming presence of Whiteness. Journal of Teacher Education, 52(2), 94-106.

Sleeter, C. E. (2008). Equity, democracy, and neoliberal assaults on teacher education. Teaching and Teacher Education, 24(8), 1947-1957.

Solanke, I. (2009). Putting race and gender together: A new approach to intersectionality. Modern Law Review, 72(5), 723-749.

Stirratt, M. J., Meyer, I. H., Ouellette, S. C., \& Gara, M. A. (2007). Measuring identity multiplicity and intersectionality: Hierarchical classes analysis (HICLAS) of sexual, racial, and gender identities. Self and Identity, 7(1), 89-111.

Tremain, S. (1996). Pushing the limits: Disabled dykes produce culture. Toronto, Canada: Women's Press.

Uys, M., Reyneke, M., \& Kaiser, K. (2011). Researching speakers of nondominant languages in teacher education programs: Tapping into perceived barriers to promote teaching and learning in diverse contexts. In A. F. Ball \& C. A. Tyson (Eds.), Studying diversity in teacher education (pp. 219-234). New York, NY: Rowman \& Littlefield.

Valenzuela, M. (1999). Expanding coverage of diversity beyond ethnicity and race. Journalism \& Mass Communication Educator, 54(2), 40-49.

Zeichner, K. M., Grant, C., Gay, G., Gillette, M., Valli, L., \& Villegas, A. M. (1998). A research informed vision for good practice in multicultural teacher education: Design principles. Theory into Practice, 37(2), 163-171.

Paul C. Gorski is an assistant professor in New Century College at George Mason University. His scholarship focuses on teacher education, economic justice, and social justice education. He founded EdChange and the Multicultural Pavilion web site. Gorski serves on the board of directors of the International Association for Intercultural Education.

Rachael D. Goodman is an assistant professor in the Counseling and Development Program at George Mason University. Her interests include social justice and multicultural training for counselors and educators. Her work also focuses on outreach and trauma counseling among marginalized communities that have experienced oppression or disaster. 